\title{
PELAKSANAAN PROMOSI DAN PENCATATAN LAPORAN KEUANGAN SEDERHANA UNTUK MENINGKATKAN PESANAN JAHITAN PADA ALLIFA COLLECTION BANDUNG
}

\author{
Dani Ramdani \\ alfarisy_dani@yahoo.com \\ Bimbim Maghriby \\ bimbim_maghriby@yahoo.com \\ Efi Fitriani \\ efi_rani@yahoo.co.id
}

\section{SEKOLAH TINGGI ILMU EKONOMI EKUITAS}

\begin{abstract}
ABSTRAK
Program pengabdian masyarakat ini bertujuan untuk memberikan pelatihan tentang metode strategi peningkatan pesanan jahitan dan pembuatan laporan keuangan keuangan sederhana pada Allifa Collection. Target khusus yang ingin dicapai dalam pengabdian ini adalah dapat meningkatkan jumlah konsumen yang menggunakan jasa Allifa Collection dan membuat laporan keuangan sederhana pada Allifa Collection. Metode yang digunakan adalah dengan memberikan pelatihan tentang strategi peningkatan pesanan jahitan melalui promosi (pamplet, brosur dan media sosial) dan pembuatan laporan keuangan sederhana. Dengan adanya pelatihan yang diberikan oleh tim, Allifa Collection diharapkan akan lebih berkembang dengan terjadinya peningkatan dalam pesanan jaitan dan adanya laporan keuangan sederhana. Dengan adanya pelatihan yang akan diberikan oleh tim pelaksana, Allifa Collection diharapkan akan lebih berkembang yaitu dengan terjadinya peningkatan jumlah konsumen dan adanya laporan keuangan sederhana. Hasil yang dicapai dari pengabdian ini adalah terlaksananya pelatihan pelaksanaan promosi melalui pembuatan pamplet dan brosur, serta pengadaan mesin jahit. Kemudian hasil lain yang dicapai adalah terjadinya peningkatan pesanan jahitan dan adanya laporan keuangan yang sederhana pada Allifa Collection.
\end{abstract}

Kata kunci: Laporan Keuangan, Promosi.

\section{PENDAHULUAN}

\subsection{Analisis Situasi}

Allifa Collection adalah usaha konfeksi yang terletak di jl. Asep Berlian No.69 Cicadas Bandung. Sejak tahun 2002 usaha konfeksi ini telah dilakukan, dimulai dengan bekerja sebagai penjahit pada konfeksi orang lain. Dengan bermodalkan pengalaman dan kompetensi keahlian menjahit, kemudian pada tahun 2008, Allifa Collection didirikan sebagai konfeksi yang mandiri. Pada tahun tersebut Allifa Collection menerima pesanan jahit dari 
pelanggan yang secara tetap masih setia menjadi konsumennya. Seiring dengan jalannya waktu maka pada tahun 2009 Allifa Collection sudah mulai merekrut 1 orang karyawan untuk membantu usaha konfeksi tersebut. Dan saat ini karyawannya berjumlah 3 orang yang terdiri dari 2 orang penjahit dan 1 orang untuk melakukan finishing.

Saat ini Allifa Collection telah memiliki 6 unit mesin yang terdiri 4 unit mesin jahit dan 2 mesin obras dan neci untuk mendukung kelancaran dalam memproduksi pakaian. Tetapi mesin jahit yang dimiliki masih model lama sehingga kinerjanya masih kurang maksimal. Sehingga mitra memerlukan mesin jahit yang baru untuk mendukung kelancaran usahanya.

Saat ini Allifa Collection Bandung melayani pesanan partai kecil dan partai besar. Tetapi pesanan yang diterima belum langsung dari pihak pertama, dikarenakan karena Allifa Collection belum dikenal luas oleh masyarakat maupun oleh instansi tertentu. Untuk partai kecil biasanya mempunyai kapasitas produksi 30 unit pakaian per minggu, sedangkan untuk partai besar mempunyai kapasitas produksi 50 unit pakaian per minggu. Sehingga dalam sebulan kapasitas produksi maksimal Allifa Collection sebesar 200 unit pakaian. Dimana hal ini merupakan kapasitas yang masih rendah jika dibandingkan dengan penjahit yang lain, adapun penjahit lain dapat memenuhi pesanan hingga 500 unit pakaian dalam sebulan. Atas rendahnya kapasitas produksi ini, diharapkan di masa yang akan datang kapasitas produksi bisa ditingkatkan sehingga pendapatan Allifa Collection juga meningkat dari pada sebelumnya.

Produksi jahitan yang dilakukan Allifa Collection berfokus pada pakaian yang telah didesain oleh pelanggan. Beberapa pelanggan meminta untuk diproduksi lebih dari satu unit pakaian. Dan ada juga pelanggan yang melakukan pesanan hanya satu unit pakaian saja. Tentunya hal ini menjadi berpengaruh pada penghasilan yang diterima oleh mitra. Karena semakin banyak pelanggan yang hanya memesan satu unit pakaian saja maka akan berpengaruh pada kapasitas produksi yang kurang maksimal. Walaupun diketahui bahwa pesanan untuk satu unit pakaian saja itu memiliki prosentasi nilai keuntungan yang lebih besar dari pada pesanan partai kecil maupun partai besar. Dengan demikian Allifa Collection diharapkan mampu menyeimbangkan produksinya sehingga dapat memperoleh keuntungan yang maksimal di masa yang akan datang.

Pendapatan rata-rata per bulan Allifa Collection adalah sekitar 10 juta rupiah. Sedangkan biaya yang akan dikeluarkan untuk karyawan adalah sebesar 30 persen dari pendapatan tersebut. Biaya untuk membayar karyawannya tergolong dalam kategori biaya variabel (variable cost), hal ini tergambar dari perilaku biaya karyawan mengikuti besarnya pesanan jahitan yang diterima oleh Allifa Collection. Semakin banyak jumlah pesanan jahitan yang akan diterima maka semakin besar pula biaya yang dikeluarkan untuk membayar karyawan. Sehingga tentunya keuntungan yang didapat Oleh Allifa Collection juga kurang maksimal. Hal ini disebabkan karena Allifa Collection masih belum mampu membayar karyawan dengan penghasilan yang tetap per bulannya. Diharapkan dari permasalahan ini, kedepannya biaya pegawai tersebut dapat terukur dengan pasti sehingga dapat diestimasikan terhadap penentuan harga jual yang wajar dengan asumsi keuntungan yang maksimal.

Secara umum, Allifa Collection Bandung memiliki permasalahan dalam manajemen waktu penyelesaian atas produksi baju yang dijahit. Hal ini berpengaruh pada waktu penyelesaian produksi lebih lama daripada yang diestimasikan dari awal. Sehingga hal ini berdampak pada berkurangnya kepercayaan konsumen pada Allifa Collection dalam hal ketepatan waktu dalam penyelesaian pesanan. 
Menurut Kotler dan Keller (2016:518), mengemukakan bahwa promosi penjualan merupakan short-term incentive untuk mendorong penjualan produk atau jasa. Dengan kata lain, sales promotion merupakan sarana untuk mendorong konsumen agar melakukan pembelian terhadap sebuah produk atau jasa.

Dalam hal promosi, Allifa Collection Bandung belum pernah melakukan promosi terhadap jasa konfeksinya. Allifa Collection belum memiliki iklan papan nama yang memadai untuk menandai tempat penjualan jasa jahitnya. Hal ini dikarenakan lokasi usaha mitra terletak pada area perumahan yang dilalui ojeg jalur gang, dimana luas jalannya yang sempit.

Allifa Collection juga belum pernah membuat brosur untuk disebarkan kepada masyarakat apalagi promosi di media sosial. Menurut Kotler \& Amstrong (2012), media sosial saat ini menjadi salah satu alat yang banyak digunakan oleh pemasar dalam menyebarkan informasi tentang suatu produk kepada konsumen. Jaringan sosial media ini merupakan bentuk baru dari dialog antara "consumer-to-consumer" dan "business-toconsumer" yang memiliki implikasi besar terhadap pemasar. Konsumen yang melakukan pesanan jahitan di Allifa Collection hanya berasal dari konsumen utamanya atau konsumen lama. Allifa Collection Bandung belum mampu memasarkan jasa konfeksinya secara mandiri. Sehingga saat ini Allifa Collection Bandung masih mengandalkan limpahan pesanan dari jasa konfeksi lain yang menjadi rekanan usaha mitra. Allifa Collection Bandung tidak dapat menentukan penetapan harga jual yang wajar atau penetapan harga jual yang sesuai dengan keuntungan yang diharapkan. Sehingga keuntungan yang diterima menjadi lebih kecil dari pada yang seharusnya diterima.

Disamping itu Allifa collection juga belum pernah membuat laporan keuangan sederhana yang mendukung usahanya sehingga biaya-biaya yang dikeluarkan dan keuntungan yang diterima tidak dicatat.

Hal yang dibutuhkan mitra saat ini adalah mesin jahit yang memadai. Melakukan kegiatan promosi dengan membuat pamplet, brosur sehingga jasa konfeksinya diketahui oleh masayarakat luas. Dengan adanya mesin jahit yang berkualitas, diharapkan produksi jahit yang dilakukannya memiliki hasil produksi yang berkualitas, memiliki penyelesaian waktu yang tepat dan memaksimalkan kapasitas produksi secara bertahap. Sehingga dengan adanya mesin jahit baru yang berkualiatas tersebut, akan mampu meningkatkan keuntungan Allifa Collection Bandung dengan rasio keuntungan yang wajar dan cukup.

Hal lain yang harus dilakukan adalah melakukan kegiatan promosi dengan membuat pamplet dan brosur sehingga jasa konfeksinya diketahui oleh masyarakat luas.

\subsection{Identifikasi Masalah}

Berdasarkan wawancara yang dilakukan oleh tim kepada mitra, maka ada beberapa masalah yang dihadapi antara lain:

$>$ Belum maksimalnya kapasitas produksi jahit dan belum memiliki mesin jait yang berkualitas

$>$ Belum melakukan promosi jasa konfeksi

$>$ Belum adanya laporan keuangan

\section{METODOLOGI PELAKSANAAN}

Metodologi pelaksanaan pada pengabdian ini menggunakan proses pelatihan dan konsultasi dengan tiga tahapan yaitu:

Tabel 1

Metode Pelaksanaan Pengabdian

\begin{tabular}{|l|l|}
\hline Tahap dan Metode & \multicolumn{2}{|c|}{ Hasil } \\
\hline Tahap Awal & Pemahaman \\
1. Melakukan & persamaan persepsi \\
interview antara & dari pihak yang \\
tim dengan & terkait, dalam hal \\
mitra untuk & ini tim dengan \\
lebih & mitra. \\
\hline
\end{tabular}




\begin{tabular}{|c|c|}
\hline $\begin{array}{l}\text { mengetahui } \\
\text { hambatan dan } \\
\text { kendala yang } \\
\text { dihadapi oleh } \\
\text { mitra } \\
\text { 2. Tim } \\
\text { memberikan } \\
\text { pemahaman atas } \\
\text { strategi } \\
\text { peningkatan } \\
\text { pesanan jahitan } \\
\text { dan pemahaman } \\
\text { dalam } \\
\text { menyusun } \\
\text { laporan } \\
\text { keuangan yang } \\
\text { sederhana } \\
\end{array}$ & \\
\hline $\begin{array}{l}\text { Tahap Pelaksanaan } \\
\text { 3. Pemaparan } \\
\text { metode strategi } \\
\text { peningkatan } \\
\text { pesanan jahitan } \\
\text { 4. Pencatatan } \\
\text { laporan } \\
\text { keuangan. }\end{array}$ & $\begin{array}{l}\text { Manual book yang } \\
\text { diberikan meliputi } \\
\text { cara-cara untuk } \\
\text { meningkatkan } \\
\text { usaha jahit agar } \\
\text { sukses dan } \\
\text { bagaimana cara } \\
\text { menerapkan } \\
\text { pembuatan laporan } \\
\text { keuangan } \\
\text { sederhana }\end{array}$ \\
\hline $\begin{array}{l}\text { Tahap Akhir } \\
\text { 5. Monitoring dan } \\
\text { Evaluasi }\end{array}$ & $\begin{array}{l}\text { Pendampingan } \\
\text { sampai terjadi } \\
\text { peningkatan } \\
\text { penjualan pesanan } \\
\text { jahitan dan sampai } \\
\text { mampu membuat } \\
\text { laporan keuangan } \\
\text { sederhana. }\end{array}$ \\
\hline
\end{tabular}

\section{HASIL DAN LUARAN}

\subsection{Hasil Kegiatan}

Dalam melakukan usahanya Allifa Collection memiliki beberapa produk yang ditawarkan untuk dijahit antara lain adalah jas, pakaian seragam kantor, kemeja, celana dan pakaian wanita dan lain-lain. Sedangkan model dan bahan pakaian yang digunakan tergantung dari pesanan yang dilakukan oleh pelanggan.
Untuk jasa jahitan tergantung model yang diminta oleh konsumen. Adapun daftar harga yang ditawarkan pada jasa konfeksi Allifa Collection adalah :

Tabel 2

Harga Jasa Jahitan Allifa Collection

\begin{tabular}{|l|l|}
\hline \multicolumn{1}{|c|}{ Jenis pakaian } & \multicolumn{1}{|c|}{ Harga Jasa } \\
\hline Jas & Rp. 150.000 \\
Kemeja laki-laki & Rp. 75.000 \\
Batik & Rp. 75.000 \\
Celana kain & Rp. 100.000 \\
Seragam kantor & Rp. 80.000 \\
\hline
\end{tabular}

Menurut artikel yang dikutip dari https://www.anhurayra.com/2018/06/meng embangkan-usaha-jahit.html, Ada Tujuh Cara Mengembangkan Usaha Jahit Agar Sukses

1. Pilihlah lokasi yang strategis

Kunci sukses usaha jahit ada pada pemilihan lokasi. Setidaknya kriteria lokasi yang pas untuk usaha menjahit adalah sebagai berikut :

- Berada dipinggir jalan desa yang ramai dilalui banyak orang.

-Lokasi ada diarea pemukiman penduduk (kalau bisa padat).

-Tidak memiliki saingan dengan radius minimal $1 \mathrm{~km}$.

Allifa Collection berada di area pemukiman penduduk yang padat tetapi lokasinya terletak di gang kecil yang jarang dilalui oleh banyak orang sehingga mungkin banyak orang yang tidak mengetahui keberadaan konfeksi tersebut. Sehingga pelanggan yang menggunakan jasa konfeksi tersebut hanya sebatas konsumen yang lama. Untuk itu Allifa Collection perlu membuat pamplet untuk mempermudah mendapatkan pelanggan yang lebih banyak. Hal ini juga bisa dilakukan kalau usaha konfeksi tersebut ingin lebih berkembang maka Allifa Collection harus bisa mempunyai sebuah kios yang letaknya lebih strategis dibanding yang sebelumnya.

Kalau dari sisi pesaing, disekitar lingkungan tersebut belum ada jasa konfeksi lainnya sehingga sebenarnya 
Allifa Collection punya potensi untuk bisa menguasai pasar daerah tersebut.

2. Perluas jangkauan promosi

Dalam dunia usaha, promosi merupakan aktifitas yang tidak boleh dilewatkan. Karena fungsi promosi adalah untuk memberitahukan atau mengenalkan produk/service yang anda miliki ke banyak orang. Hasil dari promosi adalah orang bisa tahu dan mencoba produk/service yang kita tawarkan. Tanpa promosi, bagaimana bisa orang tahu tentang usaha yang kita dirikan? Pertanyaanya, bagaimana cara promosi yang efektif, murah, namun terarah?

Yang paling mudah, anda promosikan ke semua orang yang anda kenal bisa keluarga, tetangga, teman atau siapapun. Dari proses ini, akan terbentuk promosi dari mulut ke mulut namun proses ini berlangsung cukup lama. Anda harus menambahnya dengan cara promosi yang lain.

Contohnya memasang spanduk atau papan nama yang terlihat dengan jelas didepan tempat usaha. Kalau jalan tersebut ramai, maka banyak orang juga yang bisa melihat spanduk yang kita buat.

Atau cara lainnya, anda siapkan lusinan selebaran yang isinya detail usaha anda. Lalu berikan selebaran tersebut ke tiap konsumen yang menggunakan jasa anda lalu suruh mereka menempelkan selebaran tersebut di rumah mereka, dan katakan mereka akan mendapatkan komisi apabila ada orang yang datang dari selebaran yang mereka pasang.

Dalam hal promosi, Allifa Collection belum melakukan promosi baik berupa membuat papan nama, brosur atau yang lainnya. Oleh karena itu pelanggan yang menggunakan jasa konfeksi tersebut belum terlalu banyak yaitu hanya meliputi pelanggan lama dan pelanggan daerah sekitarnya. Dari hasil pengabdian yang dilakukan beberapa waktu yang lalu, tim memberikan masukan kepada mitra untuk membuat papan nama dan brosur supaya pelaksanaan promosi dilakukan untuk meningkatkan pesanan jaitan.

3. Anda bisa manfaatkan internet

Ini disebut sistem affiliasi yang banyak digunakan oleh toko online untuk menggaet costumer lebih banyak. Di zaman yang serba digital ini, orangorang lebih lama berada di dunia maya daripada didunia nyata. Sebagai pemilik usaha, anda harus mengantisipasi kondisi ini dengan membuat promosi online. Tapi berbeda dengan promosi yang dilakukan oleh reseller.

Anda mempromosikan jasa bukannya produk, jadi promosikan kepada mereka yang memang berpotensi menggunakan jasa anda. Contohnya anda promosi di grup facebook yang mana anggotanya kebanyakan berasal dari kota anda. Jangan mempromosikan ke grup dengan anggota yang beda provinsi, karena mereka tidak mungkin datang jauh-jauh hanya untuk menjahit pakaian.

Dalam hal ini Allifa Collection belum melakukan jasa penjualan secara online. Diharapkan kedepannya promosi di media sosial dilakukan sebagai pelaksanaan promosi untuk meningkatkan pesanan jahitan.

4. Coba targetkan organisasi atau komunitas saat promosi

Biasanya tiap organisasi atau komunitas apapun itu memiliki kostum yang seragam. Dan seragam tersebut tidak mungkin dibeli di toko karena harus sama dan jumlahnya banyak. Solusinya jelas menjahit.

Apabila anda mendapatkan pesanan dari organisasi seperti ini, biasanya akan borongan dengan kata lain anda akan langsung mendapatkan pesanan berlimpah. Oleh sebab itu kalau ada organisasi/komunitas di dalam kota anda, anda bisa menawarkan ke salah satu anggotanya dengan promo dan penawaran yang menarik siapa tahu mereka akan membuat kostum lagi dan memilih anda sebagai jasa jahitnya. 
Dalam hal ini pemilik Allifa Collection harus lebih agresif lagi dalam hal melakukan pendekatan kepada suatu organisasi tertentu misalnya sekolah, kampus, kantor pemerintahan dan sebagainya. Sehingga pesanan yang akan diterima nantinya akan lebih banyak jumlahnya dari pada orang perorangan yaitu dalam bentuk partai.

5. Bila perlu tambah layanan pesan antar

Hal ini mungkin akan sedikit merepotkan tapi, kalau anda hanya menunggu pesanan dari orang lain mungkin itu sudah sangat biasa dan semua pemilik usaha jahit melakukan hal ini. Anda perlu mencoba hal lain yang membuat usaha jahit anda beda dari yang lain. Seperti menambahkan layanan pesan antar, jadi saat promosi anda siapkan nomor yang bisa dihubungi dan anda tambahkan caption "pesan antar" sehingga orang yang akan menggunakan jasa anda tidak usah repot-repot mendatangi tempat usaha anda. Tinggal telepon dan ada orang yang mendatangi rumah mereka.

Untuk layanan ini anda bisa mengenakan biaya tambahan, meski lebih mahal banyak orang yang rela keluar uang lebih demi kepraktisan.

Dalam hal ini Allifa Collection belum melakukannya disebabkan karena jumlah karyawan yang masih terbatas. Dimasa yang akan datang terobosan ini perlu dilakukan untuk mempermudah pelanggan dalam hal memesan jahitan kepada mitra.

6. Jangan ragu menambah mesin jahit dan cari beberapa karyawan

Dari beberapa strategi diatas, anda tidak akan mampu melakukannya sendiri. Anda perlu menambah aset berupa mesin jahit baru dan menambah karyawan baru baik karyawan untuk membantu anda menjahit dan juga karyawan sebagai kurir.

Tapi, banyak karyawan banyak juga pengeluaran? Memang benar, anda jangan takut dengan pengeluaran yang banyak karena pemasukan yang akan didapat juga akan lebih banyak.

Dalam hal ini penambahan mesin jahit juga sudah dilakukan oleh mitra, pada pengabdian kali ini tim memberikan satu unit mesin jahit yang sesuai dengan kebutuhan mitra. Untuk mempermudah proses kelancaran produksi jahitan, untuk itu diharapkan kedepannya Allifa Collection bisa menambah beberapa karyawan.

7. Lengkapi usaha anda dengan menjual bahan/pakaian jadi

Terakhir, anda bisa memperluas usaha anda dengan membuka toko pakaian jadi. Setahun setelah anda membuka usaha anda akan mengetahui mayoritas minat pakaian yang banyak disukai oleh costumer anda. Kalau ada waktu luang, anda bisa menjahit pakaian jadi dan menjajakan di ruangan khusus disamping usaha jahit anda.

Hal ini bisa dilakukan oleh Allifa Collection untuk beberapa tahun kedepan, karena hal ini membutuhkan modal yang lumayan besar. Seiring dengan jalannya waktu semua usaha bisnis yang dilakukan dengan sungguhsungguh, suatu saat pasti akan membawa hasil yang gemilang.

Menurut Fanani (2009), dalam laporan keuangan memiliki karakteristik relevan, handal, dapat dibandingkan dan dapat dipahami. Dalam menerapkan hal ini, Allifa Collection telah melakukan penerapan terhadap laporan keuangan sederhana yang disusunnya, adalah sebagai berikut:

1. Relevan, disini pengusaha telah membuat laporan keuangan yang dapat membantu mereka dalam mengevaluasi peristiwa ekonomi masa lalu, dan dapat melakukan perkiraan estimasi terhadap masa depan. Sehingga laporan keuangan yang telah disusun oleh pengusaha tersebut telah sesuai kriteria prinsip relevan disini.

2. Handal, disini pengusaha telah membuat laporan keuangan yang menyajikan kondisi yang sesuai dengan fakta. 
Sehingga laporan keuangan menggambarkan kondisi yang jujur dan dapat diverifikasi. Oleh karena itu, laporan keuangan yang dibuat telah menunjukan kondisi yang benar dan tidak menyesatkan. Sehingga laporan yang telah disusun oleh pengusaha tersebut telah sesuai dengan kriteria prinsip handal disini.

3. Dapat diperbandingkan, disini pengusaha telah membuat laporan keuangan sederhana yang dapat dikomparasikan dengan beberapa masa dan tahun. Adapun laporan keuangan telah disajikan per bulan dan dapat diperbandingkan dengan laporan bulan yang lain. Sehingga laporan yang telah disusun oleh pengusaha tersebut telah sesuai dengan kriteria prinsip dapat diperbandingkan disini.

4. Dapat dipahami, disini pengusaha telah membuat laporan keuangan sederhana yang dapat dipahami oleh pengusaha itu sendiri dan sebagian pengguna lain. Penggunaan istilah dalam laporan keuangan disini telah disusun dengan bahasa yang mudah dipahami dalam keilmuan ekonomi akuntansi. Sehingga laporan yang telah disusun oleh pengusaha tersebut telah sesuai dengan kriteria prinsip dapat dipahami disini.

\subsection{Luaran}

Luaran yang dihasilkan berupa manual book (peserta pelatihan) dan praktek langsung atau pelatihan langsung yang dilakukan oleh pelaku pengabdian langsung kepada peserta pelatihan. Luaran pengabdian ini adalah:

1. Peserta dapat memahami mekanisme pelaksanaa promosi untuk meningkatkan pesanan jahitan

2. Peserta dapat memahami mekanisme penyusunan laporan keuangan secara sederhana.

\section{KESIMPULAN}

Berdasarkan hasil pengabdian dapat diketahui Ada Tujuh Cara Mengembangkan Usaha Jahit Agar sukses yaitu :
1. Pilihlah lokasi yang strategis

2. Perluas jangkauan promosi

3. Anda bisa manfaatkan internet

4. Coba targetkan organisasi atau komunitas saat promosi

5. Bila perlu tambah layanan pesan antar

6. Jangan ragu menambah mesin jahit dan cari beberapa karyawan

7. Lengkapi usaha anda dengan menjual bahan/pakaian jadi.

\section{DAFTAR PUSTAKA}

Fanani, Zaenal. 2009. Kualitas Pelaporan Keuangan: Berbagai Faktor Penentu Dan Konsekuensi Ekonomis, Jurnal Akuntansi dan Keuangan Indonesia. 6: 20-45.

https://www.anhurayra.com/2018/06/meng embangkan-usaha-jahit.html

Ikatan Akuntan Indonesia. 2012. Standar Akuntansi Keuangan. Jakarta: Salemba Empat.

Kotler, Philip, dan Gary Armstrong, 2012. Prinsip-prinsip Pemasaran. Edisi 13. Jilid 1. Erlangga : Jakarta.

Kotler, Philip and Kevin Lane Keller, 2016. Marketing Management, $15^{\text {th }}$ Edition New Jersey: Pearson Pretice Hall, Inc. 